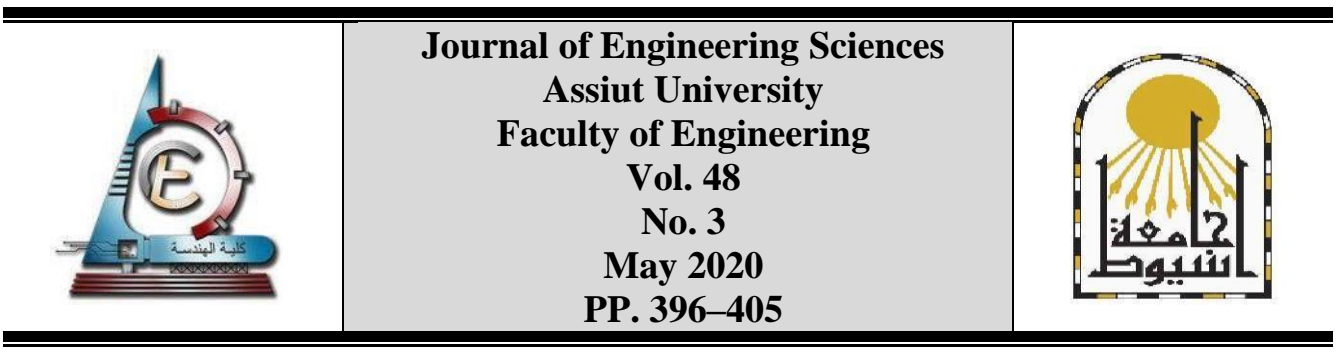

\title{
USES OF DRY VINASSE AS A FRIENDLY ENVIRONMENTALMATERIAL TO IMPROVE PROPERTIES OF CEMENT MORTAR AND CONCRETE
}

\author{
A. Megahed Ahmed ${ }^{1}$, Mohamed A. A ${ }^{2}$ and A.E.Mahmoud ${ }^{3}$ \\ ${ }^{1}$ Civil Engineering Dept. Faculty of Engineering, Assuit University, Assuit, Egypt. \\ ${ }^{2}$ Armant Sugar Factory, Egyptian Sugar \& Integrated Industries Company, Luxor, Egypt. \\ ${ }^{3}$ Mining and metallurgical Dept. Faculty of Engineering, Assuit University, Assuit, Egypt.
}

Received 2 December 2019; Accepted 20 December 2019

\begin{abstract}
This study aims at using the sugar by-product (dry vinasse), as one of the concrete production requirements, instead of getting rid of them in vain. Dry vinasse was obtained by drying liquid vinasse at $250{ }^{\circ} \mathrm{C}$. In this study, dry vinasse is used as a friendly environmental material to improve properties of cement mortar and concrete, through studying its effect on setting time and compressive strength of cement mortar and concrete. Effect of dry vinasse on compressive strength of cement mortar and concrete by using different doses of dry vinasse $0 \%, 0.2 \%, 0.3 \%, 0.4 \%$, and $0.5 \%$ by weight content of cement is studied.

Compressive strength was determined by standard specimens (40x40x160mm) for cement mortar and standard cubes specimens $(150 X 150 X 150 \mathrm{~mm})$ for concrete. By cylinder specimens $(150 \mathrm{X} 300 \mathrm{~mm})$, the splitting strength was determined and the flexural strength was determined by beam specimens $(100 X 100 X 500 \mathrm{~mm})$. All the specimens were cured in water and tested for 7 and 28days for cement mortar and concrete. The splitting strength and flexural strength were done for 28 days.

It is found that, dry vinasse addition causes increase in setting times. With comparing the results of compressive strength of cement mortar and concrete with and without dry vinasse, it is showed that, there are noticeable increases in the results of compressive strength, splitting strength and flexural strength.
\end{abstract}

Keywords: Dry Vinasse, Compressive Strength, Splitting strength, flexural strength, cement mortar, Concrete

\section{Introduction}

Molasses is considered as one of the most important by products of the sugar industry, which fully exploited in Egypt in animal nutrition and yeast industry acetone and ethyl alcohol, which led to the emergence of a new waste called vinasse. Vinasse is a liquid, produced from the fermentation of molasse to produce ethyl alcohol. Vinasse which represents a real environmental problem, it has also been a trend to dry this liquid for easy transportation and storage. Up till now this research is considered one of the first studies which studies using dry vinasse as admixture and friendly environmental material. There have been a lot of studies on the effect of sugars \& sugar by-products on cement paste and concrete.

By studying the effect of adding vinasse liquid (VSW 2016) to the concrete mixing, it is concluded that, at $2.5 \%$ from cement content is the optimum dose of the admixture (VSW 
2016) at which maximum values of compressive, splitting and Flexural strengths of concrete specimens at hardened concrete. $[1,2]$

The effect of diluted vinasse on concrete properties was studied, it is noticed that, adding diluted vinasse reduces in the amount of mixing water and increase compressive strength and indirect tensile strength. [3]

By studying the use of molasses (MKSC) and vinasses (VKSC) as concrete admixtures, the results of this study showed that addition of $0.3 \% \mathrm{MKSC}$ permitted up to $20 \%$ water content reduction, while the $5 \%$ of VKSC allowed up to $10 \%$ water reduction. [4]

The effect of sugar powder on setting time and compressive strength in both cement and concrete was investigated, the result showed that, the initial and final setting time, at $0.1 \%$ of the total weight of cement, increases, and gives improved results in compressive strength, and workability of the mortar. [5]

The effects of sugar on physical properties in both Ordinary Portland cement paste and concrete was studied, the results obtained that, at $0.06 \%$ sugar content, the initial setting time of cement paste reaches to maximum, and improves the compressive strength.[6, 7]

The effect of both sugar (Beet \& Cane) on the setting times of cement pastes was investigated, the results obtained that, adding sugar resulted in retarding the setting time under all conditions of curing. The setting time was increasing with an increase in sugar content up to $(\approx 0.15 \%)$ and then decreases with further increasing in sugar content, and this is the optimum dose for retarding the setting time. [8]

By comparing between the use of sugar and jaggery as an additive to the properties of concrete, the results of this study showed that, workability and compressive strength of concrete increases when the dose of admixture increases, concrete with Sugar as admixture has given less strength values than the Jaggery. [9]

By studying the effect of molasses on properties of cement paste, it is concluded that, the dose of $0.1 \%$ of molasses is an optimum dose. [10]

Beet molasses, as a retarding and water-reducing admixture for concrete was investigated, the compressive strength of concrete mixes with molasses increases slightly compared with those with lignosulphonate based in all ages except for early ages. The flexural strengths of concretes with molasses are in the trend with those with the lignosulphonate. [11]

Molasses in concrete, as a water reducing and retarding admixture was studied, it is found that, the higher ratios of admixtures have caused the higher water reducing; also the Setting times are getting longer with increase of admixture ratio in cement paste. At $0.4 \%$ molasses, used as a Water-reducing admixtures (Type A) and at $0.7 \%$, as a Water-reducing and retarding admixtures (Type D) in a concrete in accordance with ASTM C 494 standard. [12]

By studying the effect of molasses in concrete as admixture, it is concluded that, by increasing the dose of admixture, workability and setting time of the concrete increase. Molasses have been water reducing and retarding effect on concrete. [13]

The effect of sugar cane juice, (SCJ) on some of concrete properties was investigated, it is found that, the final setting time of concrete increases as the dose of SCJ increases, up to $25 \%$ SCJ, the compressive strength of the concrete decreases as the dose of SCJ increases.[14] 


\section{Experimental work}

The aim of present study is to investigate the effects of Sugar-Waste (Dry Vinasse) on the various properties of cement mortar and concrete. The Dry Vinasse was taken from ESIIC, whose main constituent is listed by varying the dose content of Dry Vinasse $(0.2$ $\%, 0.3 \%, 0.4 \%, 0.5 \%$ )of the cement content, the tests were carried out on three mixes with different cement contents $\left(3,3.5\right.$ and $\left.4 \mathrm{kn} / \mathrm{m}^{3}\right)$ of the cement mortar and the concrete.

This study was done as follows:

1- The setting time was compared with and without the use of Dry Vinasse for cement mortar and concrete with cement content $3.5 \mathrm{kn} / \mathrm{m}^{3}$.

2- Using standard specimens for 7 and 28days, compressive strength were determined for cement mortar, which has been worked out for different doses of Dry Vinasse $(0.2 \%, 0.3 \%, 0.4 \%$ and $0.5 \%)$ of the cement content.

3- The air-content of fresh mixed concrete by pressure method was determined at different doses of Dry Vinasse.

4- Water-reducing effect in three mixes with different cement content $(3,3.5,4$ $\mathrm{kn} / \mathrm{m}^{3}$ ) was worked out for different doses of dry vinasse.

5- Using standard cube specimens for 7 and 28days, compressive strength were determined.

6- Splitting tensile strength and flexural strength of concrete at varying doses of dry vinasse were determined.

\subsection{Material}

\subsubsection{Aggregate}

The using of fine aggregate was local natural sand and coarse aggregate was crushed stone obtain from local sources has been used. The properties of used aggregate are shown in tables No. (1\&2).

Table 1.

Properties of used aggregate.

\begin{tabular}{|c|c|c|c|c|}
\hline \multirow{2}{*}{ Property } & \multirow{2}{*}{ Sand } & \multirow{2}{*}{ Gravel } & \multicolumn{2}{|c|}{ E.S.S Limits } \\
\cline { 4 - 5 } & & & sand & gravel \\
\hline Volume weight $\left(\mathrm{t} / \mathrm{m}^{3}\right)$ & 1.63 & 1.72 & -- & - \\
\hline Specific gravity & 2.50 & 2.56 & $2.5-2.75$ & $2.5-2.75$ \\
\hline Fineness modulus & 2.74 & 7.13 & $2-3.75$ & $5-8$ \\
\hline Crushing factor $(\%)$ & -- & 18.46 & -- & $\leq 30$ \\
\hline Maximumnominal size $(\mathrm{mm})$ & -- & $20 \mathrm{~mm}$ & -- & - \\
\hline
\end{tabular}

\section{Table 2.}

Chemical properties of used aggregate.

\begin{tabular}{|c|c|c|c|c|}
\hline \multirow{2}{*}{ Property } & \multirow{2}{*}{ Gravel } & \multirow{2}{*}{ sand } & \multicolumn{2}{|c|}{ E.S.S Limits } \\
\cline { 4 - 5 } & & sand & gravel \\
\hline \% of Chloride ions content (CI) & $0.008 \%$ & 0.0514 & $\leq 0.06$ & $\leq 0.04$ \\
\hline \% of Sulfate ions content (So3) & 0.0145 & 0.155 & $\leq 0.4$ & $\leq 0.4$ \\
\hline P.H & 7.5 & 7.6 & $\geq 7$ & $\geq 7$ \\
\hline
\end{tabular}

\subsubsection{Cement}

Ordinary Portland cement (CEMI $32.5 \mathrm{~N}$ ) was used, which is produced from Assiut cement factory (CEMEX), the physical \& mechanical properties of cement are given in table (3). 
A. Megahed ahmed et al., Uses of dry vinasse as a friendly environmental material to improve ........

Table 3.

The physical \& mechanical properties of cement

\begin{tabular}{|c|l|l|c|}
\hline \multicolumn{2}{|c|}{ property } & value & E.S.S Limits \\
\hline \multicolumn{2}{|c|}{ Initial setting times (min) } & 83 & $\geq 75$ minutes \\
\hline \multicolumn{2}{|c|}{ Specific gravity } & 3.15 & - \\
\hline Specific surface area $\left(\mathrm{cm}^{2} /\right.$ gm $)$ & 3417 & $\geq 2750$ \\
\hline \multirow{2}{*}{ Compressive strength ( $\mathrm{MPa})$} & 7 day & 29.8 & $\geq 16 \mathrm{MPa}$ \\
\cline { 2 - 4 } & 28 day & 38.80 & $\geq 32.5 \mathrm{MPa}$ \\
& & $\leq 52.5 \mathrm{MPa}$ \\
\hline
\end{tabular}

\subsubsection{Mixing water}

Fresh water was used for mixing and curing of cement mortar and concrete specimens.

\subsubsection{Admixture}

Dry vinasse is obtained by drying of liquid vinasse at inlet temperature $250{ }^{\circ} \mathrm{C}$. It is collected from ESIIC, the typical properties of dry vinasse was listed in table (4).

\section{Table 4.}

Typical properties of dry vinasse.

\begin{tabular}{|c|c|c|}
\hline Parameter & Test Method & Description \\
\hline $\mathrm{pH}$ & ACAL-APR-08-01 & 5.66 \\
\hline Sulfate & ACAL-APR-21-00 & $4.658 \%(\mathrm{wt} / \mathrm{wt})$ \\
\hline Chloride & ACAL-APR-14-00 & $-\mathrm{Ve}$ \\
\hline Total sugar & ACAL-APR-33-00 & $12.88 \mathrm{~g} / \mathrm{kg}$ \\
\hline
\end{tabular}

\section{- Cement mortar Specimens}

Experimental tests have been done on 30 standard specimens, and tested under static loading up to failure.

\section{- Concrete Specimens}

Experimental tests were done on 285 standard cubes, 171 standard beams and 171 standard cylinders, then were tested under static loading up to failure according to (ESS1899-2006/1).

\section{Results and discussion}

\subsection{Effect of dry vinasse on cement mortar}

Effect of different doses of the dry vinasse $(0.2 \%, 0.3 \%, 0.4 \%$, and $0.5 \%)$ of cement content on the setting time and compressive strength of cement mortar specimens were studied, values of the setting time and compressive strength were determined. It is clear from the results that, by increasing the percentage of dry vinasse, the setting times of cement paste increase. At $0.2 \%$ dry vinasse of the cement content, compressive strength increases after 7 and 28 days by about $20 \%$ and $15 \%$ respectively compared to the control specimen, then compressive strength decreases by increasing the content of admixtures as shown in tables $(5,6)$ and Fig. (1).

Table 5.

The setting time of mortar specimens

\begin{tabular}{|c|c|}
\hline Initial setting time (min.) & Dose of Admixture \\
\hline 83 & $0.0 \%$ \\
\hline 88 & $0.2 \%$ \\
\hline 92 & $0.3 \%$ \\
\hline 111 & $0.4 \%$ \\
\hline 119 & $0.5 \%$ \\
\hline
\end{tabular}


Table 6.

Results of Compressive strength $\left(\mathrm{f}_{\mathrm{c}}\right)$ at age 7 and 28days using dry vinasse for cement mortar

\begin{tabular}{|c|c|c|}
\hline \multirow{2}{*}{$\begin{array}{c}\text { Doses of admixture } \\
\text { / cement content }\end{array}$} & \multicolumn{2}{|c|}{ Compressive strength (fc) } \\
\cline { 2 - 3 } & $\begin{array}{c}\mathrm{f}_{\mathrm{C} 7} \\
\mathrm{MPa}\end{array}$ & $\begin{array}{c}\mathrm{f}_{\mathrm{C} 28} \\
\mathrm{MPa}\end{array}$ \\
\hline $0.0 \%$ & 29.8 & 38.8 \\
\hline $0.2 \%$ & 35.7 & 44.6 \\
\hline $0.3 \%$ & 24.1 & 31.0 \\
\hline $0.4 \%$ & 26.5 & 33.5 \\
\hline $0.5 \%$ & 20.9 & 27.5 \\
\hline
\end{tabular}

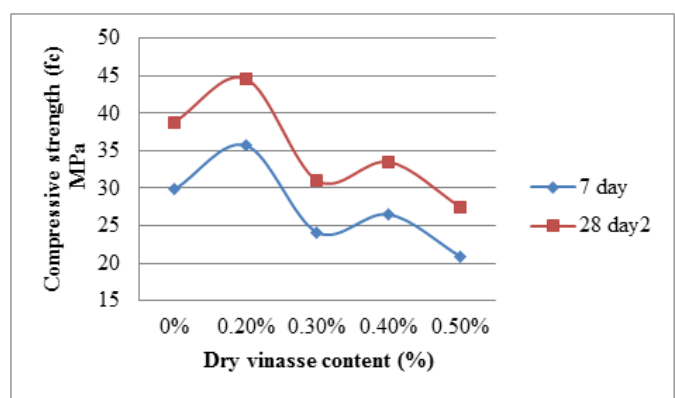

Fig. 1. Compressive strength $\left(\mathrm{f}_{\mathrm{c}}\right)$ for cement Mortar

\subsection{Effect of dry vinasse on Concrete}

\subsubsection{Fresh Concrete Properties}

\subsubsection{Consistency}

Consistency was determined by the slump test. The slump was kept ( $100-120 \mathrm{~mm})$ to be suitable for the most usages of concrete and the mixes with dry vinasse were compared with the control mix to reduce the quantity of mixing water as shown in table (7).It is clear that, dry vinasse admixture reduces the quantity of mixing water, whereas the maximum of water reduction reach $10.28 \%, 16.41 \%$ and $18.05 \%$ at cement content $3,3.5$ and $4 \mathrm{kn} / \mathrm{m}^{3}$ respectively. Accordingly, at cement content $3 \mathrm{kn} / \mathrm{m}^{3}$ the water reduction is accepted with ES : 1899-1/2006 as a water-reducing admixture and at cement content $3.5 \mathrm{kn} / \mathrm{m}^{3}$ and $4 \mathrm{kn} / \mathrm{m}^{3}$ the water reduction is accepted with ES : 1899-1/2006 as a high water-reducing admixture.

Table 7.

The results of water reduction

\begin{tabular}{|c|c|c|}
\hline $\begin{array}{c}\text { Cement } \\
\text { content } \mathrm{kn} / \mathrm{m}^{3}\end{array}$ & $\begin{array}{c}\text { Water } \\
\text { reduction \% }\end{array}$ & $\begin{array}{c}\text { Type\& Percentage } \\
\text { of a dmixture }\end{array}$ \\
\hline \multirow{4}{*}{3} & - & $0.0 \%$ \\
\cline { 2 - 3 } & $5.14 \%$ & $0.2 \%$ \\
\cline { 2 - 3 } & $6.86 \%$ & $0.3 \%$ \\
\cline { 2 - 3 } & $9.14 \%$ & $0.4 \%$ \\
\cline { 2 - 3 } & $10.28 \%$ & $0.5 \%$ \\
\hline \multirow{5}{*}{3.5} &.-- & $0.0 \%$ \\
\cline { 2 - 3 } & $11.28 \%$ & $0.2 \%$ \\
\cline { 2 - 3 } & $13.33 \%$ & $0.3 \%$ \\
\cline { 2 - 3 } & $14.87 \%$ & $0.4 \%$ \\
\hline \multirow{5}{*}{4} & $16.41 \%$ & $0.5 \%$ \\
\cline { 2 - 3 } & $11.70 \%$ & $0.0 \%$ \\
\cline { 2 - 3 } & $13.66 \%$ & $0.2 \%$ \\
\cline { 2 - 3 } & $16.10 \%$ & $0.3 \%$ \\
\cline { 2 - 3 } & $18.05 \%$ & $0.4 \%$ \\
\hline
\end{tabular}


A. Megahed ahmed et al., Uses of dry vinasse as a friendly environmental material to improve ........

\subsubsection{Setting time}

Table (8) shows the results of setting times for mixes of dry vinasse admixture with cement content $3.5 \mathrm{kn} / \mathrm{m}^{3}$.It is clear that, by increasing the percentage of dry vinasse, the initial and final setting times of concrete increases. The difference in setting time are accepted according to ESS 203/2018 when dry vinasse is used with dosage up to $0.4 \%$ of cement content where the difference is less than +90 mins.

\subsubsection{Air-Entraining}

Table (8) shows the results of air- entraining for mixes with dry vinasse admixture at cement content $350 \mathrm{~kg} / \mathrm{m}^{3} . \mathrm{It}$ is found that, the maximum of air-entraining is $3 \%$ at percentage of admixture $0.3 \%$ of cement content and the highest variance between the test mixes and the control mix is $0.6 \%$, this conforms with Egyptian Code of Practice No. 203,2018.

Table 8.

Setting times \& Air- entraining for mixes with dry vinasse

\begin{tabular}{|c|c|c|c|c|c|c|c|}
\hline \multirow{2}{*}{$\begin{array}{c}\text { Type } \\
\text { \&Percentage } \\
\text { of admixture }\end{array}$} & \multicolumn{2}{|c|}{$\begin{array}{c}\text { Air entraining } \\
\%\end{array}$} & \multicolumn{4}{|c|}{$\begin{array}{l}\text { Setting time } \\
\text { (min.) }\end{array}$} & \multirow{2}{*}{$\begin{array}{c}\text { Cement } \\
\text { content } \\
\mathrm{kn} / \mathrm{m}^{3}\end{array}$} \\
\hline & Result & Diff & Initial & Diff. & Final & Diff. & \\
\hline $0.0 \%$ & 2.4 & $\ldots$ & 215 & $\ldots$ & 345 & $\ldots$ & \multirow{5}{*}{3.5} \\
\hline $0.2 \%$ & 2.6 & 0.2 & 265 & 50 & 350 & 5 & \\
\hline $0.3 \%$ & 3 & 0.6 & 285 & 70 & 375 & 30 & \\
\hline $0.4 \%$ & 2.8 & 0.4 & 302 & 87 & 385 & 40 & \\
\hline $0.5 \%$ & 2.8 & 0.4 & 370 & 155 & 420 & 75 & \\
\hline
\end{tabular}

\subsubsection{The hardened concrete properties}

\subsubsection{Compressive strength $(f c)$}

Table (9) and Figs. $(2,3)$ show compressive strength results of concrete mixes with dry vinasse at age 7 and 28 days. In general, as for the cement content $\left(3,3.5 \mathrm{and} 4 \mathrm{kn} / \mathrm{m}^{3}\right)$, it is noticed that, the compressive strength increases by increasing dry vinasse up to $0.4 \%$, then decreases by increasing the content of dry vinasse admixture. At the cement content $3 \mathrm{kn} / \mathrm{m}^{3}$, it is noticed that, at $0.2 \%$ dry vinasse addition, the compressive strength slightly increases and clearly increases in other doses. The maximum of increase in the compressive strength at the age of 7 days reaches $78.27 \%, 56.92 \%$ and $36.40 \%$ at cement content $3,3.5,4 \mathrm{kn} / \mathrm{m}^{3}$ respectively, at the age of 28 days reaches $57.43 \%$, $45.10 \%$ and $32.31 \%$ at cement content $3,3.5,4 \mathrm{kn} / \mathrm{m}^{3}$ respectively.

\section{Table 9.}

Results of $\left(f_{c}\right)$ at age 7 and 28 days using dry vinasse

\begin{tabular}{|c|c|c|c|c|c|}
\hline \multirow{2}{*}{$\begin{array}{c}\text { Doses of } \\
\text { admixture / } \\
\text { cement content }\end{array}$} & \multirow{2}{*}{$\begin{array}{c}\text { Cement } \\
\text { content } \\
\mathrm{kn} / \mathrm{m}^{3}\end{array}$} & \multicolumn{4}{|c|}{ Compressive strength (fc) } \\
\hline & & $\begin{array}{c}\mathrm{f}_{\mathrm{c} 7} \\
\mathrm{Mpa}\end{array}$ & $f_{C} 7 / f_{C\urcorner(c)} \%$ & $\begin{array}{c}\mathrm{f}_{\mathrm{c} 28} \\
\mathrm{Mpa}\end{array}$ & $\mathrm{f}_{\mathrm{C} 2 \mathrm{~S}} / \mathrm{f}_{\mathrm{c} 2 \mathrm{~g}(\mathrm{c})} \%$ \\
\hline $0.0 \%$ & \multirow{5}{*}{3} & 16.8 & 100 & 24.9 & 100 \\
\hline $0.2 \%$ & & 18.1 & 107.73 & 27.7 & 111.25 \\
\hline $0.3 \%$ & & 28.7 & 170.83 & 38.8 & 155.82 \\
\hline $0.4 \%$ & & 30.0 & 178.57 & 39.2 & 157.43 \\
\hline $0.5 \%$ & & 22.4 & 133.33 & 34.4 & 138.15 \\
\hline $0.0 \%$ & \multirow{5}{*}{3.5} & 19.5 & 100 & 28.6 & 100 \\
\hline $0.2 \%$ & & 24.3 & 124.62 & 34.3 & 119.93 \\
\hline $0.3 \%$ & & 29.7 & 152.31 & 40.1 & 140.21 \\
\hline $0.4 \%$ & & 30.6 & 156.92 & 41.5 & 145.10 \\
\hline $0.5 \%$ & & 27.3 & 140 & 37.0 & 129.37 \\
\hline $0.0 \%$ & \multirow{5}{*}{4} & 23.9 & 100 & 32.5 & 100 \\
\hline $0.2 \%$ & & 28.4 & 118.83 & 35.2 & 108.31 \\
\hline $0.3 \%$ & & 31.0 & 129.71 & 40.5 & 124.61 \\
\hline $0.4 \%$ & & 32.6 & 136.40 & 43.0 & 132.31 \\
\hline $0.5 \%$ & & 29.9 & 125.10 & 39.6 & 121.84 \\
\hline
\end{tabular}




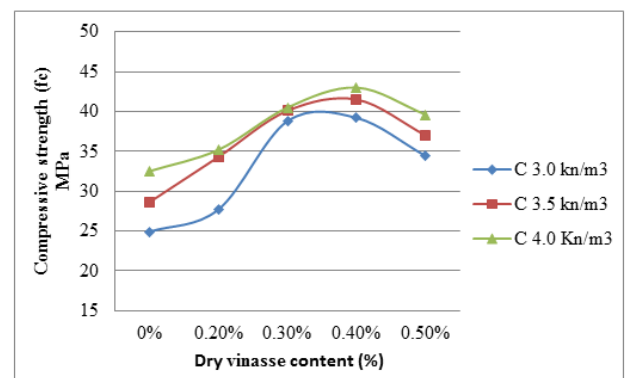

Fig. 2. Compressive strength $\left(f_{c}\right)$ at 7 days using dry vinasse

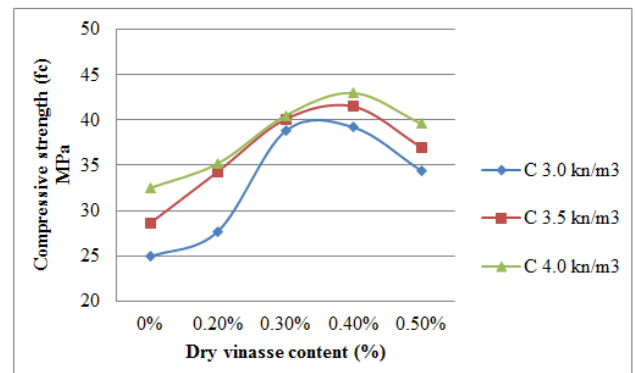

Fig. 3. Compressive strength $\left(f_{c}\right)$ at 28 days using dry vinasse

\subsubsection{Indirect tensile strength}

\subsection{Splitting strength}

Table (10) and Fig. (4), show the results of splitting strength $\left(\mathrm{F}_{\mathrm{sp}}\right)$ of concrete mixes with dry vinasse at age 28 days, the results show that, the addition of dry vinasse causes significant improvement in the results of splitting strength compared to control mixes. The maximum increase in the splitting strength at the age of 28 days reaches $52.14 \%, 51.04 \%$ and $44.63 \%$ at cement content $3.0,3.5,4.0 \mathrm{kn} / \mathrm{m}^{3}$ respectively.

Table 10.

Splitting Strength $\left(\mathrm{F}_{\mathrm{sp}}\right)$ results of concrete mixes with dry vinasse

\begin{tabular}{|c|c|c|c|}
\hline \multirow{2}{*}{$\begin{array}{l}\text { Doses of } \\
\text { admixture/ } \\
\text { cement content }\end{array}$} & \multirow{2}{*}{$\begin{array}{l}\text { Cement } \\
\text { content } \\
\mathrm{kn} / \mathrm{m}^{3}\end{array}$} & \multicolumn{2}{|c|}{ Splitting strength $\mathrm{f}_{\mathrm{sp}}$} \\
\hline & & $\mathrm{f}_{\mathrm{sp} 28 \mathrm{MPa}}$ & $f_{s p 28} / f_{5 p 28 c} \%$ \\
\hline $0.0 \%$ & \multirow{5}{*}{3.0} & 1.99 & 100 \\
\hline $0.2 \%$ & & 2.05 & 103.12 \\
\hline $0.3 \%$ & & 2.79 & 140.42 \\
\hline $0.4 \%$ & & 3.03 & 152.14 \\
\hline $0.5 \%$ & & 2.57 & 129.26 \\
\hline $0.0 \%$ & \multirow{5}{*}{3.5} & 2.17 & 100 \\
\hline $0.2 \%$ & & 2.37 & 109.12 \\
\hline $0.3 \%$ & & 3.05 & 140.40 \\
\hline $0.4 \%$ & & 3.28 & 151.04 \\
\hline $0.5 \%$ & & 2.55 & 117.60 \\
\hline $0.0 \%$ & \multirow{5}{*}{4.0} & 2.31 & 100 \\
\hline $0.2 \%$ & & 2.55 & 110.40 \\
\hline $0.3 \%$ & & 3.19 & 138.10 \\
\hline $0.4 \%$ & & 3.34 & 144.63 \\
\hline $0.5 \%$ & & 2.94 & 127.47 \\
\hline
\end{tabular}




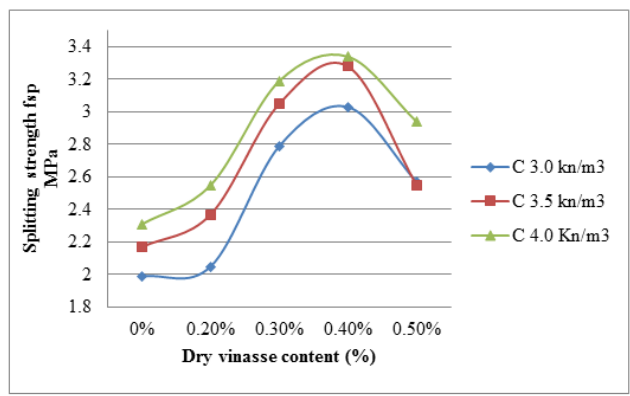

Fig. 4. Splitting strength $\mathrm{f}_{\mathrm{sp}}$ at 28 days

\subsection{Flexural Strength (Fcr)}

The results of flexural strength of concrete mixes with dry vinasse at age 28 days increases by increasing doses up to $0.4 \%$ then decreases. The maximum increase in the flexural strength reaches $22.6 \%, 23.17 \%$ and $38.82 \%$ for cement content of $3.0,3.5,4.0$ $\mathrm{kn} / \mathrm{m}^{3}$ respectively as shown in table (11) and Fig. (5).

Table 11.

Flexural Strength $\left(\mathrm{F}_{\mathrm{cr}}\right)$ results of concrete mixes with dry vinasse

\begin{tabular}{|c|c|c|c|}
\hline \multirow{2}{*}{$\begin{array}{c}\text { Doses of } \\
\text { admixture / } \\
\text { cement content }\end{array}$} & \multirow{2}{*}{$\begin{array}{l}\text { Cement } \\
\text { content } \\
\mathrm{kn} / \mathrm{m}^{3}\end{array}$} & \multicolumn{2}{|c|}{ Flexural strength $f_{c r}$} \\
\hline & & $\begin{array}{l}\mathrm{F}_{\mathrm{cr} 28} \\
\mathrm{MPa}\end{array}$ & $\begin{array}{c}F_{c r 28} / F_{s p 128(c)} \\
\%\end{array}$ \\
\hline Control mix & \multirow{5}{*}{3.0} & 4.16 & 100 \\
\hline $0.2 \%$ & & 4.26 & 102.5 \\
\hline $0.3 \%$ & & 5.04 & 121.21 \\
\hline $0.4 \%$ & & 5.10 & 122.66 \\
\hline $0.5 \%$ & & 4.92 & 118.33 \\
\hline Control mix & \multirow{5}{*}{3.5} & 4.73 & 100 \\
\hline $0.2 \%$ & & 5.12 & 108.36 \\
\hline $0.3 \%$ & & 5.75 & 121 \\
\hline $0.4 \%$ & & 5.82 & 123.17 \\
\hline $0.5 \%$ & & 5.58 & 118.1 \\
\hline Control mix & \multirow{5}{*}{4.0} & 5.00 & 100 \\
\hline $0.2 \%$ & & 5.30 & 106 \\
\hline $0.3 \%$ & & 6.43 & 128.57 \\
\hline $0.4 \%$ & & 6.94 & 138.82 \\
\hline $0.5 \%$ & & 6.14 & 122.78 \\
\hline
\end{tabular}

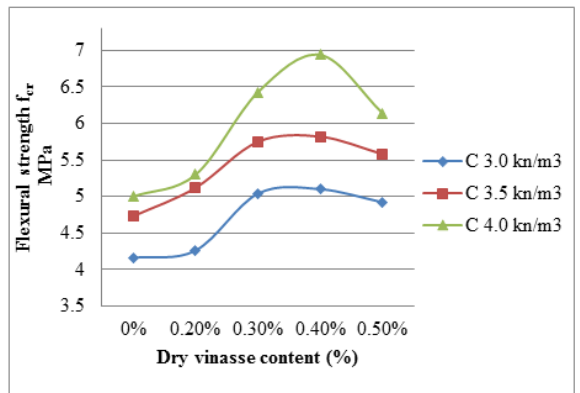

Fig. 5. Flexural strength $f_{\text {cr }}$ at 28 days

\section{Conclusions}

For mortar, the addition of dry vinasse causes an increase in compressive strength at 0.2 $\%$ dry vinasse then decreases. The most favourable dose of dry vinasse is $0.2 \%$ dose. 
For concrete, the addition of dry vinasse achieves reducing in the quantity of mixing water, and it causes a noticeable increase in compressive strength, flexural strength and splitting strength compared to control mixes. The most favourable dose of dry vinasse is $0.4 \%$ dose. In conclusion, results obtained in the present study can be drawn for the effects of dry vinasse on the cement mortar and concrete as follows:

- The setting times of cement-paste increase by increasing dry vinasse addition with respect to the selected doses.

- For cement mortar, compressive strength increases by increasing dry vinasse up to $0.2 \%$, then it decreases by increasing the content of admixtures.

- At cement content $3.0 \mathrm{kn} / \mathrm{m}^{3}$ the water reduction are accepted with ES : 1899-1/2006 as a water-reducing admixture and at cement content $3.5 \mathrm{kn} / \mathrm{m}^{3}$ and $4.0 \mathrm{kn} / \mathrm{m}^{3}$ the water reduction are accepted with ES : 1899-1/2006 as a high water-reducing admixture.

- The setting time of concrete increases as the dose of dry vinasse increases.

- Results of Air - entraining percentages for test mixes, which contains of dry vinasse with cement content $3.5 \mathrm{kn} / \mathrm{m}^{3}$ conform to Egyptian code of practice No 203, 2018.

- For concrete the compressive strength increases as the dose of dry vinasse increases up to $0.4 \%$, then decreases.

- The addition of dry vinasse causes noticeable increase in flexural strength and splitting strength compared to control mixes.

In future studied: It is hoped that take into consideration the effect of dry vinasse on durability of concrete and steel.

\section{REFERENCES}

[1] A. Megahed Ahmed, Mohamed M. A, Omar A, F. and Shawky M. H. "Improvement of the concrete characteristics by using sugar industry wastes (vinasse)" Journal of Engineering Sciences, Faculty of Engineering, Assiut University,46, 2, 2018, 142 - 159.

[2] Megahed Ahmed, Mohamed M. A, Omar A, F. and Shawky M. H."Characteristics and Durability of Concrete Containing Sugar Industry Wastes (Vinasse) Exposed To Aggressive Environmental Conditions" Journal of Engineering Sciences, Faculty of Engineering, Assiut University,46, 3, 2018, 282 - 298.

[3] Omar F. , Said H. , Amal B. and Shawky M.H " Using sugar industry wastes ( Vinasse ) as a plasticizer concrete admixture enhancing durability consideration " International conference on innovation building materials, Egypt (HBRC), 2014.

[4] Sara Tageldin Hassan M. M.sc Dissertation "Use of Sudanese molasses and vinassesas concrete admixtures ", Civil Dept., Faculty of Engineering. Khartoum University, Dec. 2013.

[5] Yogesh. R. Suryawanshi, Pankaj N. Bhat, R. R. Shinde, S. B. Pawar\&Namrata Mote, "Experimental Study On Effect Of Sugar Powder On Strength Of Cement" International Journal of Research in Engineering \& Technology, 2,4, 2014, 249-252.

[6] Abalaka, AE, "Effects of Sugar on Physical Properties of Ordinary Portland Cement Paste and Concrete", AUJT, 3, 14, 2011, 225-228.

[7] Abalaka, AE, "Comparative Effects of Cassava Starch and Simple Sugar in Cement Mortar and Concrete", ATBU Journal of Environmental Technology,1,4, 2011, 13-22.

[8] Bazid Khan and Bulent Baradan, "The Effect of Sugar on Setting -Time of Various type of Cements", Science Vision, 8(1), 2002, 71-78.

[9] Giridhar.V, Gnaneswar. K and Kishore Kumar Reddy. P, “ Effect of Sugar and Jaggery on Strength Properties of Concrete", The International Journal Of Engineering And Science, 2,10, 2013, 1-6 
A. Megahed ahmed et al., Uses of dry vinasse as a friendly environmental material to improve ........

[10] El Zamzami, MA, Ali, MOM \&Awad, ME,"The effect of molasses and VZ4 addition on the properties of cement paste and concrete", Building and road research journal, 3, 2000, 25-34.

[11] Amanmyrat Jumadurdiyeva, M. Hulusi Ozkula, Ali R. Saglamb, Nazmiye Parlak, "The utilization of beet molasses as a retarding and water-reducing admixture for concrete" Cement and Concrete Research, 35, 2005, 874-882.

[12] Hasan Yildirim and Baris Altun, "Usage of Molasses in concrete as a water reducing and retarding admixture", Indian Journal of Engineering and Materials Sciences, 19, 2012, 421-426.

[13] Somawanshi, S. P., Ansari, U.S and karale, S. A., "Effect Of Molasses In Concrete As A Water Reducing And Time Retarding Admixture", International Journal of Recent Scientific Research, 7, 9, 2016, 13417-13421.

[14] A. W. Otunyo, S. C. Onwusiri and N. Nwaiwu, "Effect of Sugar Cane Juice on Slump Values, Setting Times Andstrength Of Concrete" Nigerian Journal of Technology, 34, 2, 2015, 254 - 258.

[15] Egyptian code of practice No 203, 2018.

\section{استخدامات الفيناس الجاف كمادة صديقة للبيئة لتحسين خصائص المونة الاسمنتية والخرسانة}

\section{الملخص العربى}

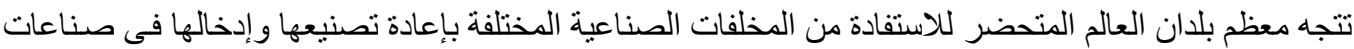

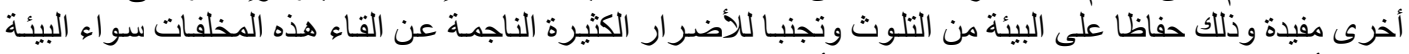

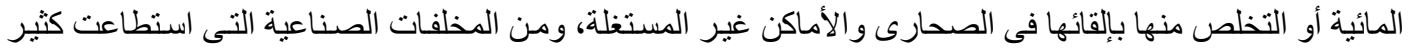

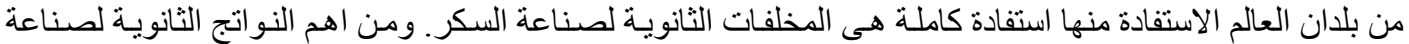

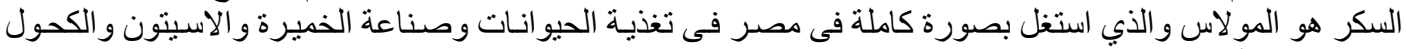

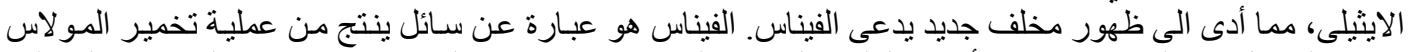

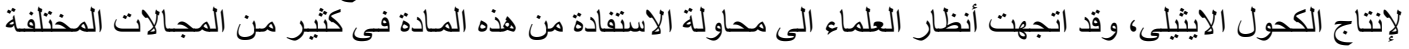

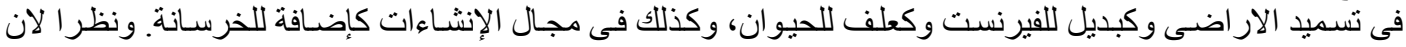

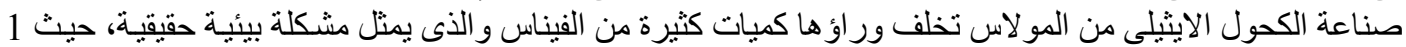

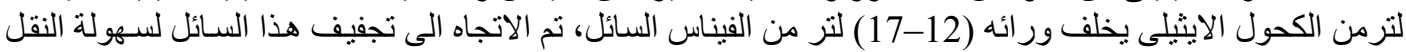

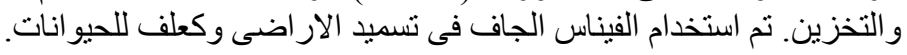

وحيث إن مجال الإنشاءات يستهلك كمية كبيرة من الموارد الطبيعية و المخلفات الصناعية، لذا يهدف هذا البحثث

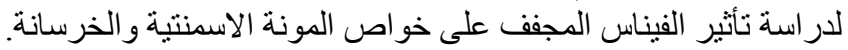

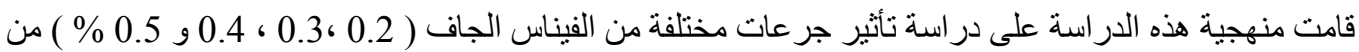

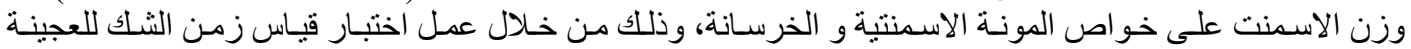

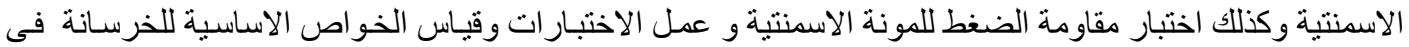

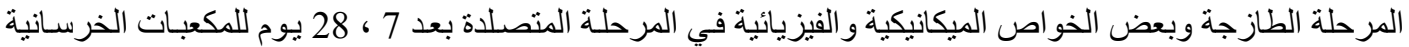

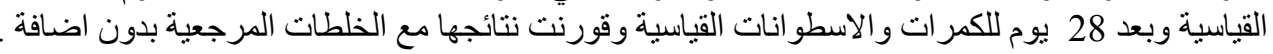

نتائج هذه الدر اسة بصفة عامة اوضحت ان اضاء اضفة الفيناس المجفف قد حققت تحسن ملحوظ على خو اص الخرسـانة سواء الطازجة او المتصلدة. حيث تشير النتائج الى الآتي: - ماه

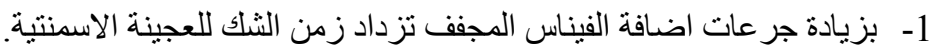

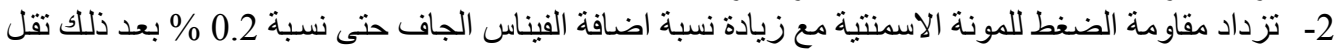

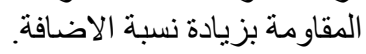

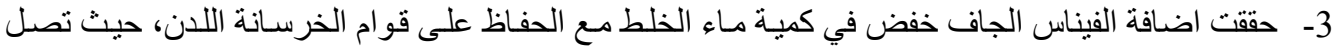

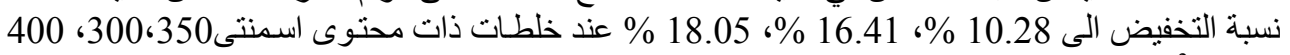

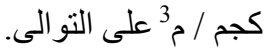

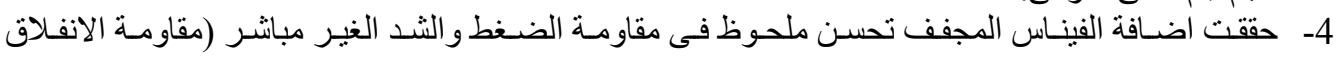
والانحناء) للخرسانة. 